\title{
Kesadaran Mahasiswa Terhadap Penggunaan Edible Flowers Sebagai Garnish Dalam Penyajian Makanan (Studi Kasus: Mahasiswa Pengolah Makanan Pada Program Studi Pariwisata Universitas Pendidikan Indonesia dan STP Bandung)
}

\author{
Ricky Pratama Suwandi, Dewi Turgarini, Rattikah Fitrianti \\ Indonesia University of Education, Jl. Dr. Setiabudhi No. 229, Bandung 40154, \\ Indonesia \\ * Koresponding Penulis. E-mail: rickypratamasuwandi@upi.edu (Ricky Pratama \\ Suwandi)
}

\begin{abstract}
ABSTRAK
Penelitian ini dilakukan dengan tujuan untuk mengetahui kesadaran mahasiswa terhadap penggunaan edible flowers sebagai garnish pada penyajian makanan mereka. Penelitian kualitatif deskriptif merupakan metode penelitian yang digunakan dengan cara observasi, studi dokumentasi, dan penyebaran kuesioner/angket. Mahasiswa program studi Manejemen Industri Katering (UPI), Pendidikan Tata Boga (UPI), Manajemen Tata Boga (STPB), dan Manajemen Patiseri (STPB) merupakan populasi dari penelitian ini. Teknik penentuan sampel pada penelitian kali ini adalah random sampling sebanyak 85 orang. Data dianalisis dengan menggunakan teknik analisis data deskriptif kuantitatif dan kualitatif. Berdasarkan hasil penelitian dapat diambil kesimpulan bahwa kesadaan mahasiswa terhadap penggunaan edible flowers dalam kategori cukup baik dan kesadaran mahasiswa terhadap dampak edible flowers pada makanan dalam kategori baik.
\end{abstract}

Keywords: Edible Flowers; Kesadaran Mahasiswa; Garnish; Penyajian Makanan.

First Received:

Oktober 2014

\section{Revised:}

Oktober 2014
Accepted:

November 2014

Final Proof Received: November 2014

Published: Desember 2014 


\section{Pendahuluan}

Tampilan makanan yang cantik pada saat disajikan nampaknya merupakan poin tambah bagi sebagian orang karena wisata kuliner bagi sebagian orang sekarang bukan lagi hanya soal rasa makanannya saja yang dicari, tetapi juga tampilan makanan yang disajikan cenderung instagram-able untuk keperluan update story di media sosialnya masing-masing.

Untuk menampilkan sajian makanan yang menarik, pelaku kuliner harus memperhatikan faktor-faktor yang akan disajikan bersama makanan diatas piring, salah satunya dengan menambahkan garnish atau penghias makanan untuk makin mempercantik tampilan makanan yang disajikan.

Penggunaan edible flower sebagai penghias diatas piring memang bisa diandalkan sebagai garnish apalagi dengan bentuk yang cantik dan warna yang kontras dengan makanan. Edible flowers dapat digunakan untuk menambah daya tarik dan terlihat lebih berkelas yang karena itu dipakai banyak orang yang berhubungan dengan makanan, salah satunya adalah mahasiswa yang memiliki praktik memasak karena mereka bisa menggunakan edible flowers diatas piring-piring makanan yang mereka telah buat.

Setelah saya menyebar kuesioner prapenelitian kepada 45 orang responden, didapatkan hasil bahwa sekitar 13\% responden tidak mengetahui nama dari edible flowers yang mereka gunakan dan sekitar 22\% tidak mengetahui rasa edible flowers yang mereka gunakan. Sekitar $76 \%$ tidak banyak tahu tentang nama edible flowers yang mereka gunakan dan sekitar $62 \%$ responden tidak banyak tahu tentang rasa dari edible flowers yang mereka gunakan. Sesuai dengan hasil penelitian yang dilakukan oleh Guiné, Florenca, Villalobos, dan Anjos (2020) yang mengatakan bahwa sebagian besar masyarakat umum mengetahui edible flowers tetapi sebagian besar dari mereka pun belum cukup informasi atau pemahaman tentang itu.
Oleh sebab itu, saya pikir perlu adanya penelitian lebih lanjut tentang hal ini. Diharapkan dengan adanya penelitian ini dapat meningkatkan kesadaran dan pengetahuan mahasiswa tentang edible flowers jika mereka ingin menggunakannya agar mahasiswa tahu apa yang mereka sajikan di atas piring.

\section{Studi Literatur}

\subsection{Kesadaran}

Hasibuan (2012, hlm. 193) mendefinisikan kesadaran sebagai sikap seseorang yang secara sukarela menaati semua peraturan dan sadar akan tugas dan tanggung jawabnya. Sedangkan menurut Lesmana (2020) kesadaran merupakan keadaan dimana diri mengetahui atau mengingat dan terlintas ataupun terasa di diri pada suatu hal ditambah respon dari diri terhadap hal tersebut. Adapun indikator atau dimensi kesadaran menurut Priyono (1996) adalah pengetahuan dan pemahaman.

\subsubsection{Pengetahuan}

Menurut Mubarak (2011), pengetahuan merupakan segala sesuatu yang diketahui berdasarkan pengalaman manusia itu sendiri dan pengetahuan akan bertambah sesuai dengan proses pengalaman yang dialaminya. Pengetahuan adalah hasil tahu seseorang setelah melakukan penginderaan (penciuman, pendengaran, pengelihatan, perasaan, dan perabaan) terhadap suatu objek, namun sebagian besar pengetahuan didapat lewat indra pendengaran dan pengelihatan (Notoatmodjo, 2014).

\subsubsection{Pemahaman}

Pemahaman menurut Sudijono (2011, hlm. 50) adalah kemampuan seseorang untuk mengerti atau memahami sesuatu dan setelah itu diketahui dan diingat. Sementara Widiasworo (2017, hlm. 81) mendefinisikan pemahaman sebagai kemampuan untuk menghubungkan atau mengasosiasikan informasi-informasi yang sudah dipelajari dan tersimpan menjadi sesuatu yang utuh di otak kita. 


\subsection{Mahasiswa}

Mahasiswa merupakan seseorang yang terdaftar di salah satu perguruan tinggi apapun bentuk perguruan tinggi tersebut (universitas, institut, akademik, dll) dan sedang dalam proses belajar atau menjalani pendidikan (Hartaji, 2012, hlm. 5). Mahasiswa dapat dikatakan sebagai seseorang yang dikategorikan sedang dalam tahap perkembangan berumur 18 sampai 25 tahun atau dapat digolongkan sebagai remaja akhir atau dewasa awal dan dilihat dari segi perkembangan, tugas perkembangan di usia mahasiswa ini merupakan pemantapan pendirian hidup (Yusuf, 2012).

\subsection{Penyajian Makanan}

Menurut Deroy, Michel, PiquerasFiszman, dan Spence (2014) penyajian makanan lebih dari sekadar stimulasi visual, tetapi juga memengaruhi rasa hidangan itu sendiri. Sejalan dengan Michel, Velasco, Gatti, dan Spence (2014) yang mengutarakan bahwa penyajian makanan dengan cara artistik dinilai memiliki rasa yang lebih enak daripada makanan yang mengandung bahan yang sama yang disajikan dengan cara yang lebih sederhana.

Visualisasi tampilan makanan yang baik telah menjadi faktor yang penting dalam mempengaruhi kepuasan seseorang dalam menciptakan sebuah pengalaman yang tidak terlupakan (Putra, Anantadjaya, dan Nawangwulan, 2020). Paresti, Nuswantari, Sukri, dan Chaerudin (2017) menyebutkan juga beberapa hal yang perlu diperhatikan dalam penyajian makanan, yaitu kombinasi warna, bentuk, tekstur, dan kekentalan, rasa dan suhu, alat saji makan, hiasan / garnish, dan penyajian.

\subsection{Hiasan Makanan}

Menurut Guggenmos dan McVety (2010, hlm. 509) garnish berasal dari kata bahasa Perancis yaitu "Garnir" yang memiliki arti menghias atau melengkapi. Dalam kuliner, garnish digunakan untuk membuat sajian makanan lebih menarik. Nunung (2011, hlm. 2) mendefinisikan garnish sebagai hiasan pada makanan yang berfungsi mempercantik penampilan hidangan sehingga menambah selera makan. Karina dan Amrihati (2017, hlm. 214) memnagi jenis garnish menjadi dua, yaitu garnish sederhana dan garnish kombinasi.

\subsection{Edible Flowers}

Edible flowers dapat diartikan sebagai bunga yang tidak beracun, bunga yang tidak berbahaya dan memiliki manfaat kesehatan untuk makanan manusia (Alasalvar dkk, 2013). Dalam penambahan edible flowers dapat mempengaruhi tekstur, rasa, tampilan makanan, dan kandungan bioaktif (Rivas-García dkk, 2021). Sejalan dengan itu, Husti, Cantor, Buta \& Hort (2013) menyebutkan bahwa sejak jaman roma kuno, edible flowers digunakan untuk memperkuat rasa dan aroma, sepercik warna, tekstur pada sup, makanan penutup, salad, dan minuman, atau hanya sebagai pelengkap suatu sajian.

\subsection{Sejarah Edible Flowers}

Penggunaan edible flowers dalam masakan sudah ada sejak zaman kuno, tetapi belakangan ini semakin sukses di kalangan konsumen, semakin memperhatikan makanan sehat dan berkualitas tinggi, tanpa mengabaikan rasa, rasa, dan daya tarik visual (Drava, Iobbi, Govaerts, Minganti, Copetta, Ruffoni, \& Bisio, 2020). Edible flowers telah dikonsumsi secara tradisional dalam berbagai budaya (Fernandes, Casal, Pereira, Saraiva, dan Ramalhosa, 2017).

Di Indonesia, menurut Prabawati (2018) makanan nusantara sudah lazim menggunakan bunga sebagai bahan bakunya. Di banyak daerah bahkan makanan berbahan bunga sangat populer dan umum disantap, contohnya seperti tumis bunga pepaya, sambal honje atau bunga kecombrang, pecel kembang turi, sayur besan khas Betawi yang mana menggunakan bunga terubuk, dan masih banyak masakan lainnya yang memanfaatkan bunga yang ada disekitar rumah tinggal atau kebunnya. 


\section{Metode Penelitian}

3.1 Jenis dan Metode Penelitian

Metode yang digunakan dalam penelitian ini adalah metode deskriptif dan jenis penelitian ini adalah penelitian kualitatif.

\subsection{Waktu dan Tempat Penelitian}

Penelitian ini dilaksanakan dengan cara observasi kepada penjual edible flowers yaitu Setiabudi Supermarket, IJO Edible Flower, Sweet Lovage, dan Garnish Edible Flower untuk mengetahui jenis edible flowers yang tersedia dan dapat mahasiswa gunakan. Peneliti juga menyebar kuesioner atau angket kepada mahasiswa Manajemen Industri Katering, Universitas Pendidikan Indonesia (UPI), Pendidikan Tata Boga, UPI. Manajemen Patiseri, Sekolah Tinggi Pariwisata Bandung (STPB), dan Manajemen Tata Boga, STPB. Pengumpulan data dilaksanakan pada tanggal 17 Juni 2021 sampai 25 Juni 2021.

\subsection{Populasi dan Sampel}

Populasi dari penelitian ini adalah mahasiswa bidang kuliner atau yang terkait dengan pengolahan makanan yang berada di Universitas Pendidikan Indonesia dan STP Bandung yang sudah melakukan praktik memasak yaitu berjumlah 556 mahasiswa. Untuk menentukan jumlah sampel, peneliti menggunakan rumus Slovin sebagai berikut:

$$
\begin{gathered}
n=\frac{N}{1+\mathrm{Ne}^{2}} \\
n=\frac{556}{1+556(0,1)^{2}}=84,7 \approx 85
\end{gathered}
$$

Berdasarkan perhitungan diatas, maka ukuran sampel minimal dalam penelitian ini ditetapkan dengan $\alpha=0,10$ diperoleh ukuran sampel (n) sebanyak 85 responden.

\subsection{Teknik Pengambilan Sampel}

Peneliti menggunakan teknik proportional stratified random sampling, yang dapat diartikan bahwa proportional stratified random sampling ialah teknik pengambilan sampel dengan cara menarik sampel dari setiap sub-populasi dan jumlahnya disesuaikan dengan jumlah anggota dari masing-masing sub populasi secara acak dengan tujuan untuk memperoleh sampel yang representatif dengan melihat populasi mahasiswa yang ada di Universitas Pendidikan Indonesia dan STP Bandung yang berstrata, yakni terdiri beberapa program studi yang heterogen (tidak sejenis).

\subsection{Teknik Pengumpulan Data}

\section{a. Observasi}

Metode observasi yang akan dilakukan oleh Peneliti adalah dengan langsung ke lapangan untuk mencari tahu apa edible flowers yang mahasiswa dapatkan dan gunakan untuk garnish di atas piring mereka. Lapangan yang dimaksud adalah tempat-tempat yang menjual edible flowers baik itu supermarket, toko fisik pejual edible flowers, atau toko online yang menjual edible flowers.

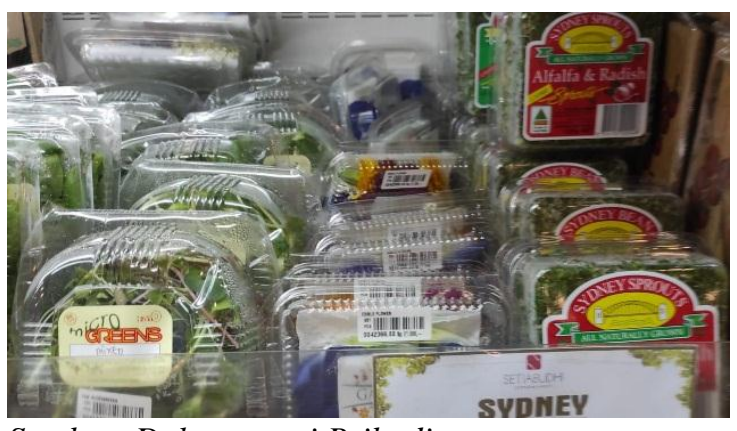

Sumber: Dokumentasi Pribadi

Gambar 1. Dokumentasi observasi di Setiabudi Supermarket

\section{b. Kuesioner / Angket}

Metode penelitian ini akan dilakukan oleh peneliti dengan menyebar kuesioner kepada mahasiswa pengolah makanan di UPI dan STP Bandung. Kuesioner disebar guna mengetahui kesadaran mahasiswa. Berikut peneliti akan memaparkan pertanyaan dan pernyataan pada kuesioner yang disebar pada tabel 1 untuk pertanyaan terbuka, tabel 2 dan 3 untuk pernyataan variabel $\mathrm{x}$ atau pemahaman, dan tabel 4 untuk variabel y atau edible flowers. 
Tabel 1. Pertanyaan Terbuka

\begin{tabular}{cl}
\hline No. & \multicolumn{1}{c}{ Pertanyaan } \\
\hline 1 & $\begin{array}{l}\text { Jika tersedia, apakah Anda akan } \\
\text { memilih edible flowers sebagai }\end{array}$ \\
& garnish? \\
2 & $\begin{array}{l}\text { Apa menurut Anda food plating } \\
\text { yang menggunakan edible flowers } \\
\text { lebih menarik dibanding yang } \\
\text { tidak? }\end{array}$ \\
\hline & Sumber: Data diolah peneliti, 2021
\end{tabular}

Tabel 2. Pernyataan dimensi pengetahuan

\begin{tabular}{cl}
\hline No. & \multicolumn{1}{c}{ Pernyataan } \\
\hline 1 & $\begin{array}{l}\text { Saya tertarik untuk menggunakan } \\
\text { edible flowers sebagai garnish } \\
\text { dalam makanan saya. }\end{array}$ \\
2 & $\begin{array}{l}\text { Saya merasa percaya diri jika } \\
\text { memakai edible flowers dalam }\end{array}$ \\
food plating saya. \\
Saat akan food plating dan belum \\
tahu rasa dari bunga yang akan \\
saya gunakan, saya mencicipinya \\
terlebih dahulu agar mengetahui \\
rasanya. \\
$\begin{array}{l}\text { Saya menaruh edible flowers di } \\
\text { atas piring tanpa tahu rasa dari } \\
\text { edible flowers tersebut. }\end{array}$ \\
5 Saya mencari tahu terlebih dahulu \\
nama bunga yang akan saya \\
gunakan jika saya belum tahu. \\
Saya menaruh edible flowers di \\
atas piring tanpa tahu nama dari \\
edible flowers tersebut. \\
Lingkungan sekitar saya biasa \\
menggunakan edible flowers \\
sebagai garnish pada hasil praktik \\
Saya pernah mendapat materi \\
tentang edible flowers selama \\
perkuliahan.
\end{tabular}

Tabel 3. Pernyataan dimensi pemahaman

\begin{tabular}{cl}
\hline No. & \multicolumn{1}{c}{ Pernyataan } \\
\hline 1 & $\begin{array}{l}\text { Saya dapat memberi contoh edible } \\
\text { flowers yang cocok dengan suatu } \\
\text { makanan. }\end{array}$ \\
2 & $\begin{array}{l}\text { Saya dapat memberi contoh } \\
\text { bagaimana cara menggunakan } \\
\text { edible flowers yang baik dan }\end{array}$ \\
benar. & $\begin{array}{l}\text { Saya dapat mengklasifikasi-kan } \\
\text { edible flowers menurut rasa. }\end{array}$ \\
4 & $\begin{array}{l}\text { Saya dapat mengklasifikasikan } \\
\text { edible flowers menurut warna. }\end{array}$ \\
5 & $\begin{array}{l}\text { Saya dapat mengklasifikasikan } \\
\text { edible flowers menurut tekstur. }\end{array}$ \\
6 & $\begin{array}{l}\text { Saya dapat membandingkan bunga } \\
\text { yang layak pakai dan tidak. }\end{array}$ \\
7 & $\begin{array}{l}\text { Saya dapat menjelaskan } \\
\text { bagaimana cara menggunakan } \\
\text { edible flowers dengan baik. }\end{array}$ \\
\hline & $\begin{array}{l}\text { Sumber: Data diolah peneliti, 2021 } \\
\text { Samata }\end{array}$
\end{tabular}

Tabel 4. Pernyataan variabel y

\begin{tabular}{|c|c|}
\hline No. & Pernyataan \\
\hline 1 & $\begin{array}{l}\text { Saya mengetahui tekstur edible } \\
\text { flowers yang saya gunakan dan } \\
\text { pengaruhnya terhadap makanan } \\
\text { yang saya sajikan. }\end{array}$ \\
\hline 2 & $\begin{array}{l}\text { Saya mengetahui rasa edible } \\
\text { flowers yang saya gunakan dan } \\
\text { pengaruhnya terhadap makanan } \\
\text { yang saya sajikan. }\end{array}$ \\
\hline 3 & $\begin{array}{l}\text { Saya sadar bahwa edible flowers } \\
\text { dapat mempengaruhi tampilan } \\
\text { makanan. }\end{array}$ \\
\hline
\end{tabular}

c. Dokumentasi

Dalam peneltian ini, peneliti menggunakan metode dokumentasi dengan mengambil dan menggunakan foto-foto untuk mengumpulkan data-data yang diperlukan selama penelitian berlangsung.

\subsection{Teknik Analisis Data}

\subsubsection{Data}

Setelah mendapatkan data dari angket atau kuesioner yang disebar, penulis akan mencari skor rata-rata dengan rumus dari Sugiyono (2010, hlm 43) sebagai berikut: 
Variabel X:

$$
\mathrm{Me}=\frac{\sum X i}{n} \quad \mathrm{Me}=\frac{\sum Y i}{n}
$$

Variabel Y:

Keterangan:

$\mathrm{Me} \quad=$ rata-rata $($ mean $)$

$\sum \mathrm{Xi}=$ Jumlah nilai $\mathrm{X}$ ke- $\mathrm{i}$ sampai ke- $\mathrm{n}$

$\sum Y \mathrm{i}=$ Jumlah nilai Y ke- $\mathrm{i}$ sampai ke- $\mathrm{n}$

$\mathrm{N} \quad=$ jumlah responden

Setelah peneliti mendapatkan hasil rata-rata, peneliti akan mengkategorikan dalam kriteria penafsiran berikut ini:

Tabel 5. Kriteria Penafsiran

\begin{tabular}{cc}
\hline Rata-rata & Penafsiran \\
\hline $1,00-1,79$ & Sangat Tidak Baik \\
$1,80-2,59$ & Tidak Baik \\
$2,60-3,39$ & Cukup Baik \\
$3,40-4,19$ & Baik \\
$4,20-5,00$ & Sangat Baik \\
\multicolumn{2}{c}{ Sumber: Abdurrahman \& Sambas, 2007, } \\
\multicolumn{2}{c}{ disesuaikan }
\end{tabular}

\subsubsection{Data Kualitatif}

Teknik analisis data yang peneliti lakukan untuk metode kualitatif ini merujuk seperti yang dikemukakan oleh Bungin (2003, hlm. 70) yaitu pengumpulan data, lalu reduksi data, dilanjutkan dengan penyajian data, dan terakhir dengan penarik kesimpulan.

\section{Hasil dan Pembahasan}

\subsection{Hasil Observasi}

Berdasarkan data yang peneliti peroleh dari observasi, berikut edible flowers yang tersedia di 4 tempat yang menjual edible flowers.

Tabel 6. Edible flowers yang tersedia di Setiabudi Supermarket

\begin{tabular}{cc}
\hline No. & Jenis edible flowers \\
\hline 1 & Anyelir / Dianthus
\end{tabular}

\begin{tabular}{ll}
2 & Kembang Girang / Elderflower \\
3 & Kenikir / Cosmos \\
4 & Mahrit / Aster \\
5 & Mata Kucing / Torenia \\
6 & Phlox \\
7 & Salaira / Lantana \\
8 & Bunga Tahi Ayam / Marigold \\
9 & Bunga Telang / Butterfly pea \\
\hline & Sumber: Data diolah peneliti, 2021
\end{tabular}

Berdasarkan tabel diatas, Setiabudi Supermarket menjual 9 jenis edible flowers yang mana dijual secara per pack yang berisi satu jenis atau bermacam jenis.

Tabel 7. Edible flowers yang tersedia di IJO Edible Flower

\begin{tabular}{cl}
\hline No. & \multicolumn{1}{c}{ Jenis edible flowers } \\
\hline 1 & Anyelir / Dianthus \\
2 & Anyelir Besar / Giant Dianthus \\
3 & Bunga Pentas / Star Flower \\
4 & Daisy \\
5 & Kenikir / Cosmos \\
6 & Mata Kucing / Torenia \\
7 & Mawar mini / Mini Rose \\
8 & Nasturtium \\
9 & Pansy \\
10 & Phlox \\
11 & Salvia \\
12 & Bunga Tahi Ayam / Marigold \\
13 & Verbena \\
14 & Viola \\
\hline & Sumber: Data diolah peneliti, 2021
\end{tabular}

Berdasarkan tabel diatas, terdapat 14 edible flowers yang dijual di IJO Edible Flower dan bunga disini dijual secara satuan.

Tabel 8. Edible flowers yang tersedia di Sweet Lovage

\begin{tabular}{cl}
\hline No. & \multicolumn{1}{c}{ Jenis Edible Flowers } \\
\hline 1. & Anyelir / Dianthus \\
2. & Begonia \\
3. & Bunga Bawang Putih / Garlic \\
& Flowers \\
4. & Bunga Lokio / Chives Flowers \\
5. & Bunga Pacar Air / Impatien \\
6. & Bunga Pentas / Star Flowers
\end{tabular}


7. Kembang Girang / Elder Flowers

8. Kenikir / Cosmos

9 Kenop / Gomphrena

10. Lilac

11. Mahrit

12. Mata Kucing / Torenia

13. Mawar Mini / Baby Rose

14. Nasturtium

15. Pansy

16. Phlox

17. Saliara / Lantana

18. Tahi Ayam / Marigold

19. Telang / Butterfly Pea

20. Viola

Sumber: Data diolah peneliti, 2021

Berdasarkan tabel diatas, Sweet Lovage menjual 20 jenis edible flowers dengan sistem penjualan secara satuan.

Tabel 9. Edible flowers yang tersedia di GARNISH Edible Flower

\begin{tabular}{cl}
\hline No. & \multicolumn{1}{c}{ Jenis Edible Flowers } \\
\hline 1. & Anyelir / Dianthus \\
2. & Anyelir Besar / Great Dianthus \\
3. & Borage \\
4. & Bunga Adas / Dill Flower \\
5. & Bunga Bawang Putih / Garlic \\
& Flower \\
6. & Bunga Jagung / Corn Flower \\
7. & Bunga Pentas / Star Flower \\
8. & Calendula \\
9. & Daisy \\
10. & Geranium / Pelargonium \\
11. & Kamperfuli / Honey Suckle \\
12. & Kembang Girang / Elder flower \\
13. & Kenikir / Cosmos \\
14. & Kenop / Gomphrena \\
15. & Lilac \\
16. & Mahrit \\
17. & Mata Kucing / Torenia \\
18. & Mawar Mini / Baby Rose \\
19. & Nasturtium \\
20. & Pansy \\
21. & Phlox \\
22. & Salvia \\
23. & Tahi Ayam/ Marigold \\
24. & Telang / Butterfly Pea \\
25. & Verbena \\
26. & Viola \\
\hline
\end{tabular}

Sumber: Data diolah peneliti, 2021

Berdasarkan tabel diatas, GARNISH Edible Flower memiliki 26 jenis edible flowers yang mana dijual secara perpack.

\subsection{Rekapitulasi Tanggapan Responden Terkait Alasan Menggunakan Edible Flowers \\ Dari total 85 orang sampel, 83 orang} responden menjawab akan menggunakan edible flowers sebagai garnish jika tersedia dengan alasan mengikuti perkembangan zaman di dunia kuliner, dapat menambah daya tarik visual, rasa, dan aroma pada hidangan karena memiliki beragam variasi warna, bentuk, dan aroma, lebih simpel dan praktis jadi mudah digunakan dan hemat waktu. Sementara 2 orang lainnya menjawab tidak juga dengan alasan banyak bahan lain yang dapat menghasilkan bentuk, rasa, dan tekstur lebih beragam dan dilihat dari tema suatu masakannya terlebih dahulu.

\subsection{Rekapitulasi Tanggapan Responden} Tentang Perbedaan Menggunakan Edible Flowers dan Tidak.

Dari total sampel 85 orang responden terdapat 45 orang atau sekitar 53\% menjawab "Ya" terkait penyajian makanan menggunakan edible flowers lebih menarik dibanding yang tidak dengan alasan terlihat lebih mewah, elegan, berwarna, segar, unik, hidup, dan estetik, dapat menambah pengalaman tersendiri bagi sebagian orang, membantu makanan lebih menarik perhatian, dan dapat menambah selera makan. Sedangkan 40 orang responden atau sekitar 47\% menjawab "Tidak Juga" dengan alasan tergantung dari keahlian tangan dalam tata letak makanan dan mengatur warna di atas piring, tergantung pemakaian dari edible flowers dan konsep makanan itu sendiri, dan dapat menggunakan bahan lain yang tidak harus edible flowers untuk memberi kesan menarik. 


\subsection{Tanggapan Responden Terkait Dimensi Pengetahuan Variabel X \\ Dalam kuesioner yang peneliti sebar,} dalam dimensi pengetahuan ini terdapat 11 butir pernyataan yang terdiri dari pernyataan favorable atau positif dan unfavorable atau pernyataan negatif. Untuk pernyataan unfavorable terdapat pada nomor 4 dan 6 dan peneliti telah mengubah bobot 1,2,3,4 dan 5 menjadi 5, 4, 3, 2, dan 1 sebelum diteliti.

Tabel 10. Pernyataan dimensi pengetahuan

\begin{tabular}{|c|c|c|c|}
\hline No. & Pernyataan & Skor & $\begin{array}{l}\text { Rata- } \\
\text { rata }\end{array}$ \\
\hline 1 & $\begin{array}{l}\text { Saya tertarik } \\
\text { untuk } \\
\text { menggunakan } \\
\text { edible flowers } \\
\text { sebagai garnish } \\
\text { dalam makanan } \\
\text { saya. }\end{array}$ & 377 & 4,44 \\
\hline 2 & $\begin{array}{l}\text { Saya merasa } \\
\text { percaya diri jika } \\
\text { memakai edible } \\
\text { flowers dalam } \\
\text { food plating saya. }\end{array}$ & 345 & 4,06 \\
\hline 3 & $\begin{array}{l}\text { Saat akan food } \\
\text { plating dan } \\
\text { belum tahu rasa } \\
\text { dari bunga yang } \\
\text { akan saya } \\
\text { gunakan, saya } \\
\text { mencicipinya } \\
\text { terlebih dahulu } \\
\text { agar mengetahui } \\
\text { rasanya. }\end{array}$ & 340 & 4 \\
\hline 4 & $\begin{array}{l}\text { Saya menaruh } \\
\text { edible flowers di } \\
\text { atas piring tanpa } \\
\text { tahu rasa dari } \\
\text { edible flowers } \\
\text { tersebut. }\end{array}$ & 302 & 3,55 \\
\hline 5 & $\begin{array}{lr}\text { Saya mencari } \\
\text { tahu terlebih } \\
\text { dahulu nama } \\
\text { bunga yang akan } \\
\text { saya gunakan jika } \\
\text { saya belum tahu. }\end{array}$ & 344 & 4,05 \\
\hline
\end{tabular}

6 Saya menaruh $319 \quad 3,75$ edible flowers di atas piring tanpa tahu nama dari edible flowers tersebut.

7 Lingkungan $\quad 309 \quad 3,64$ sekitar saya biasa menggunakan edible flowers sebagai garnish pada hasil praktik

8 Saya pernah mendapat materi tentang edible flowers selama perkuliahan.

9 Saya memiliki $261 \quad 3,07$ informasi cukup terkait namanama edible flowers.

10 Saya memiliki $227 \quad 2,67$ informasi cukup terkait rasa dari edible flowers.

11 Saya memiliki $270 \quad 3,18$ informasi cukup tentang bagaimana menggunakan edible flowers yang baik dan benar.

Rata-Rata $\quad 305 \quad 3,59$ Sumber: Data diolah peneliti, 2021

Berdasarkan pada data yang disajikan di tabel 4.8, tanggapan responden terkait pengetahuan memperoleh nilai rata-rata sebesar 3,59 yang didapat dari jumlah ratarata total skor dibagi dengan jumlah responden (305/85).

Berdasarkan tabel 5 mengenai kriteria penafsiran, garis kontinum dimensi pengetahuan dari variabel kesadaran dapat dilihat pada gambar dibawah ini:

\begin{tabular}{ccccc}
$\begin{array}{c}\text { Sangat } \\
\text { Tidak }\end{array}$ & Tidak & Cukup & Baik & Sangat \\
Baik & Baik & Baik & & Baik \\
& & & & \\
\hline
\end{tabular}




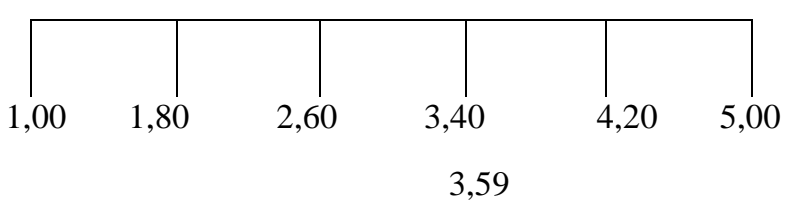

Sumber: Diolah peneliti, 2021

Figure 1. Garis Kontinum Dimensi Pengetahuan.

Dari Figure 1 diatas, dapat dilihat bahwa skor rata-rata 3,59 berada di dalam kategori baik yaitu diantara skor 3,40 4,20. Berdasarkan kriteria penafsiran, dengan skor 3,59 dapat diambil kesimpulan bahwa pengetahuan responden baik.

\subsection{Tanggapa Responden Terkait Dimensi Pemahaman Variabel X}

Tabel 11. Pernyataan dimensi pemahaman

\begin{tabular}{|c|c|c|c|}
\hline No. & Pernyataan & Skor & $\begin{array}{c}\text { Rata- } \\
\text { rata }\end{array}$ \\
\hline 1 & \begin{tabular}{lr}
\multicolumn{2}{l}{ Saya dapat memberi } \\
contoh & edible \\
flowers yang & cocok \\
dengan & suatu \\
makanan. &
\end{tabular} & 260 & 3,06 \\
\hline 2 & $\begin{array}{l}\text { Saya dapat memberi } \\
\text { contoh bagaimana } \\
\text { cara menggunakan } \\
\text { edible flowers yang } \\
\text { baik dan benar. }\end{array}$ & 276 & 3,25 \\
\hline 3 & $\begin{array}{l}\text { Saya dapat } \\
\text { mengklasifikasi- } \\
\text { kan edible flowers } \\
\text { menurut rasa. }\end{array}$ & 199 & 2,34 \\
\hline 4 & $\begin{array}{l}\text { Saya dapat } \\
\text { mengklasifikasikan } \\
\text { edible flowers } \\
\text { menurut warna. }\end{array}$ & 287 & 3,38 \\
\hline 5 & $\begin{array}{l}\text { Saya dapat } \\
\text { mengklasifikasikan } \\
\text { edible flowers } \\
\text { menurut tekstur. }\end{array}$ & 224 & 2,64 \\
\hline 6 & $\begin{array}{l}\text { Saya dapat } \\
\text { membandingkan } \\
\text { bunga yang layak } \\
\text { pakai dan tidak. }\end{array}$ & 354 & 4,16 \\
\hline 7 & $\begin{array}{ll}\text { Saya } & \text { dapat } \\
\text { menjelaskan } & \\
\text { bagaimana } & \text { cara } \\
\text { menggunakan } & \end{array}$ & 264 & 3,11 \\
\hline
\end{tabular}

\author{
edible flowers \\ dengan baik. \\ Rata-rata \\ Sumber: Data diolah peneliti, 2021
}

Dapat dilihat pada tabel 11 tentang tanggapan responden terkait pemahaman memiliki skor rata-rata keseluruhan 3,13 yang didapat dari yang didapat dari jumlah rata-rata total skor dibagi dengan jumlah responden (266/85).

Berdasarkan tabel 5 mengenai kriteria penafsiran, garis kontinum dimensi pemahaman dari variabel kesadaran dapat dilihat pada gambar dibawah ini:

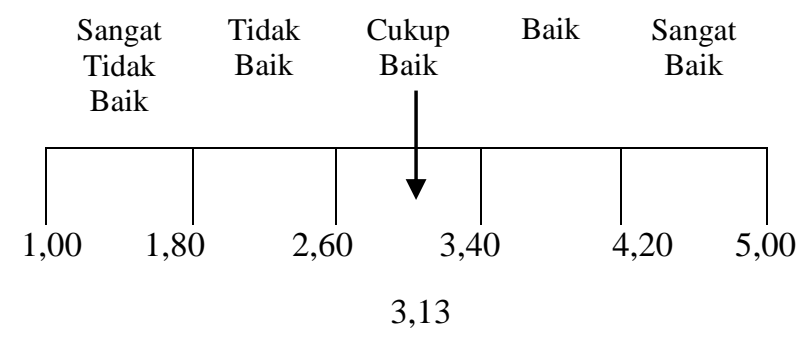

Sumber: Diolah peneliti, 2021

Figure 2. Garis Kontinum Dimensi Pemahaman.

Dari Figure 2 diatas, dapat dilihat bahwa skor rata-rata 3,13 berada di dalam kategori cukup baik yaitu diantara skor 2,60 - 3,40. Berdasarkan kriteria penafsiran, dengan skor 3,13 dapat diambil kesimpulan bahwa pemahaman responden cukup baik.

\subsection{Rekapitulasi Hasil Tanggapan Variabel X}

Mencari skor rata-rata variabel $\mathrm{x}$ Skor rata-rata kesadaran

$$
\begin{aligned}
& =\frac{\text { Rata }- \text { rata pengetahuan }+ \text { rata }- \text { rata pemahaman }}{2} \\
& =\frac{3,59+3,13}{2} \\
& =3,36
\end{aligned}
$$

Berdasarkan tabel 5 mengenai kriteria penafsiran, garis kontinum variabel $\mathrm{X}$ atau kesadaran dapat dilihat pada gambar dibawah ini: 


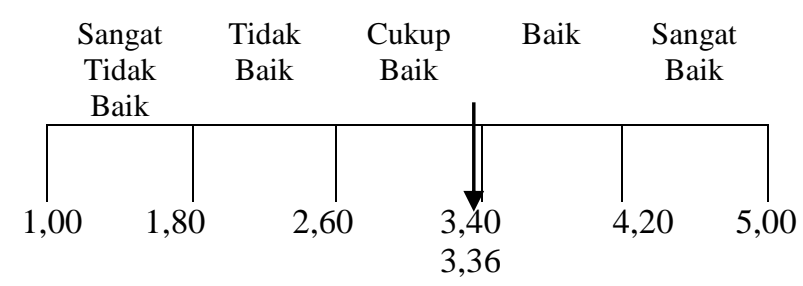

Sumber: Diolah peneliti, 2021

Figure 3. Garis Kontinum Variabel X.

Dari Figure 3 diatas, dapat dilihat bahwa skor rata-rata 3,36 dan berada di dalam kategori cukup baik yaitu diantara skor 2,60 - 3,40. Berdasarkan kriteria penafsiran, dengan skor 3,36 dapat diambil kesimpulan bahwa kesadaran responden cukup baik.

\subsection{Tanggapan Responden Terkait Tekstur Variabel Y}

Tabel 12. Pernyataan dimensi tekstur

\begin{tabular}{rlcc}
\hline No. & \multicolumn{1}{c}{ Pernyataan } & $\begin{array}{c}\text { Skor } \\
\text { Rata- } \\
\text { rata }\end{array}$ \\
\hline 1 & Saya mengetahui & $\mathbf{2 6 1}$ & $\mathbf{3 , 0 7}$ \\
& tekstur edible & & \\
& flowers yang saya & \\
& gunakan dan \\
& pengaruhnya \\
& terhadap makanan \\
& yang saya sajikan. \\
\hline & Sumber: Data diolah peneliti, 2021
\end{tabular}

Dengan berdasar pada data yang diperoleh, tanggapan responden terkait tekstur memperoleh nilai rata-rata sebesar 3,07 yang didapat dari jumlah total skor dibagi dengan jumlah responden (261/85).

Berdasarkan tabel 5 mengenai kriteria penafsiran, garis kontinum dimensi tekstur dari variabel edible flowers dapat dilihat pada gambar dibawah ini:

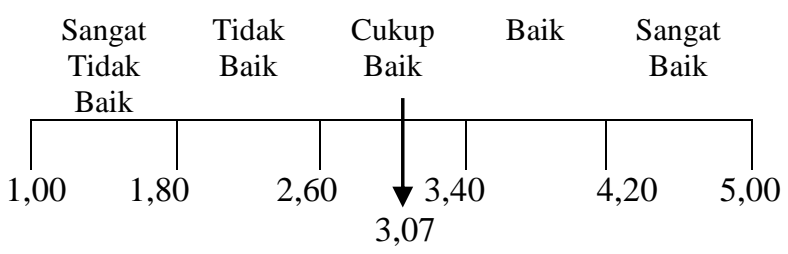

Sumber: Diolah peneliti, 2021

Figure 4. Garis Kontinum Dimensi Tekstur.

Dari figure 4 diatas, dapat dilihat bahwa skor rata-rata 3,07 berada di dalam kategori cukup baik yaitu diantara skor 2,60 - 3,40. Berdasarkan kriteria penafsiran, dengan skor 3,07 dapat diambil kesimpulan bahwa kesadaran responden tentang tekstur cukup baik.

\subsection{Tanggapan Responden Terkait Rasa Variabel Y}

Tabel 13. Pernyataan dimensi rasa

\begin{tabular}{rlcc}
\hline No. & Pernyataan & $\begin{array}{c}\text { Skor } \\
\text { Rata- } \\
\text { rata }\end{array}$ \\
\hline 1 & Saya mengetahui & $\mathbf{2 6 4}$ & $\mathbf{3 , 1 1}$ \\
& rasa edible flowers \\
& yang saya gunakan \\
& dan pengaruhnya & \\
& terhadap makanan \\
& yang saya sajikan. \\
\hline & Sumber: Data diolah peneliti, 2021 \\
& Dengan berdasar pada data yang
\end{tabular}
diperoleh, tanggapan responden terkait tekstur memperoleh nilai rata-rata sebesar 3,11 yang didapat dari jumlah total skor dibagi dengan jumlah responden (261/85).

Berdasarkan tabel 5 mengenai kriteria penafsiran, garis kontinum dimensi rasa dari variabel edible flowers dapat dilihat pada gambar dibawah ini:

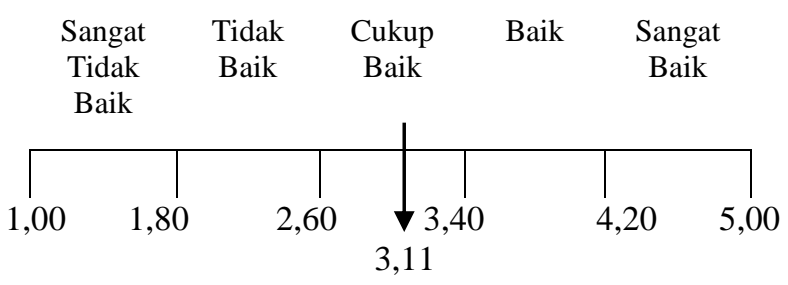

Sumber: Diolah peneliti, 2021

Figure 5. Garis Kontinum Dimensi Rasa.

Dari figure 5 diatas, dapat dilihat bahwa skor rata-rata 3,11 berada di dalam kategori cukup baik yaitu diantara skor 2,60 - 3,40. Berdasarkan kriteria penafsiran, dengan skor 3,11 dapat diambil kesimpulan bahwa kesadaran responden tentang rasa edible flowers cukup baik.

\subsection{Tanggapan Responden Terkait Dimensi Tampilan Variabel Y}

Tabel 14. Pernyataan dimensi tampilan 


\begin{tabular}{rlcc}
\hline No. & \multicolumn{1}{c}{ Pernyataan } & $\begin{array}{c}\text { Skor } \\
\text { Rata- } \\
\text { rata }\end{array}$ \\
\hline 1 & $\begin{array}{l}\text { Saya sadar bahwa } \\
\text { edible flowers } \\
\text { dapat }\end{array}$ & 4,56 \\
& & \\
& mempengaruhi \\
tampilan makanan. & \\
\hline & Sumber: Data diolah peneliti, 2021
\end{tabular}

Berdasarkan Tabel 14, tanggapan responden terkait rasa memperoleh hasil rata-rata sebesar 4,56 yang didapat dari jumlah total skor dibagi dengan jumlah responden (388/85).

Berdasarkan tabel 5 mengenai kriteria penafsiran, garis kontinum dimensi tampilan dari variabel edible flowers dapat dilihat pada gambar dibawah ini:

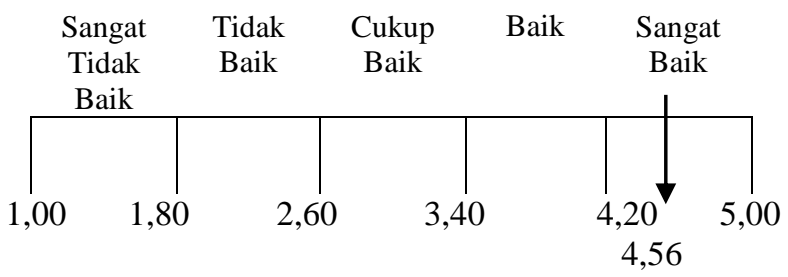

Sumber: Diolah peneliti, 2021

Figure 6. Garis Kontinum Dimensi Tampilan.

Dari figur 6 diatas, dapat dilihat bahwa skor rata-rata 4,56 berada di dalam kategori sangat baik yaitu diantara skor 4,20 - 5,00. Berdasarkan kriteria penafsiran, dengan skor 4,56 dapat diambil kesimpulan bahwa kesadaran responden tentang tampilan makanan oleh edible flowers sangat baik.

\subsection{Rekapitulasi Tanggapan Responden Terkait Variabel Y}

Mencari skor rata-rata variabel $\mathrm{x}$

Skor rata-rata kesadaran

$=$

$\underline{\text { Rata-rata (tekstur }+ \text { rasa+tampilan) }}$

$=\frac{3,07+3,11+4,56}{3}$
$=3,58$

Berdasarkan tabel 5 mengenai kriteria penafsiran, garis kontinum edible flowers dapat dilihat pada gambar dibawah ini:

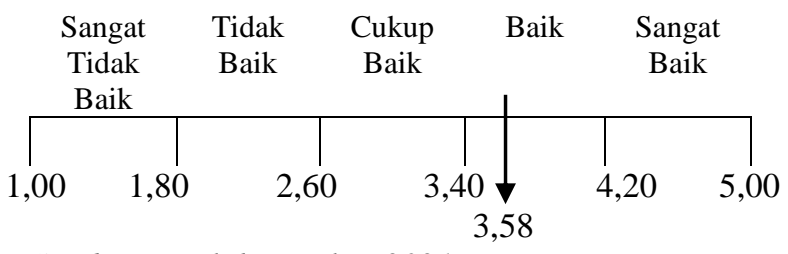

Sumber: Diolah peneliti, 2021

Figure 7. Garis Kontinum Dimensi Tampilan.

Dari gambar 4.11 diatas, dapat dilihat bahwa skor 3,58 dari skor maksimal dan berada di dalam kategori baik yaitu diantara skor 3,40 - 4,20. Berdasarkan kriteria penafsiran, dengan skor 3,58 dapat diambil kesimpulan bahwa hasil dari responden adalah baik.

\section{Kesimpulan}

Berdasarkan hasil observasi yang peneliti lakukan pada 4 tempat yang menjual edible flowers, didapatkan setidaknya toral 30 jenis edible flowers yang dapat dengan mudah didapat dan digunakan oleh mahasiswa untuk dijadikan sebagai garnish. Jenis-jenis bunga tersebut antara lain bunga anyelir, anyelir besar, begonia, borage, bunga adas, bunga bawang putih, bunga jagung, bunga lokio, bunga pacar air, bunga pentas, calendula, daisy, geranium, kamperfuli, kembang girang, kenikir, kenop, lilac, mahrit, mata kucing, mawar mini, nasturtium, pansy, phlox, saliara, salvia, bunga tahi ayam, telang, verbena, dan viola.

Sebanyak 34 orang atau sekitar 98\% orang responden beralasan menggunakan edible flowers karena mengikuti perkembangan zaman di dunia kuliner, dapat menambah daya tarik visual, rasa, dan aroma pada hidangan karena memiliki beragam variasi warna, bentuk, dan aroma, lebih simpel dan praktis jadi mudah digunakan dan hemat waktu. Sedangkan 2 orang atau kurang lebih $2 \%$ dari responden mengatakan bahwa belum tentu memilih untuk menggunakan walau tersedia karena banyak bahan lain yang dapat 
menghasilkan bentuk, rasa, dan tekstur lebih beragam dan dilihat dari tema suatu masakannya terlebih dahulu.

Sekitar 53\% responden atau 45 orang menjawab penyajian makanan dengan edible flowers lebih menarik dibanding dengan yang tidak. Dengan alasan makanan jadi terlihat lebih mewah, elegan, berwarna, segar, unik, hidup, dan estetik, dapat menambah pengalaman tersendiri bagi sebagian orang, membantu makanan lebih menarik perhatian, dan dapat menambah selera makan. Sedangkan $47 \%$ responden menjawab tidak juga atau belum tentu dengan alasan tergantung dari keahlian tangan dalam tata letak makanan dan mengatur warna di atas piring, tergantung pemakaian dari edible flowers dan konsep makanan itu sendiri, dan dapat menggunakan bahan lain yang tidak harus edible flowers untuk memberi kesan menarik.

Kesadaran responden terhadap penggunaan edible flowers sebagai garnish memiliki rata-rata dalam kriteria cukup baik. Nilai yang tertinggi dalam hasil penelitian ini berada pada minat responden terhadap penggunaan edible flowers dan yang terendah merupakan informasi mengenai rasa dan mengklasifikasikan bunga berdasarkan rasa.

Kesadaran responden terhadap dampak dari penggunaan edible flowers terhadap makanan mendapat rata-rata nilai dengan kategori baik. Nilai tertinggi berada pada pernyataan terkait dampak penggunaan edible flowers terhadap tampilan makanan. Sedangkan nilai terendah berada di pernyataan terkait dampak tekstur pada makanan yang disebabkan oleh penggunaan edible flowers.

\section{Daftar Pustaka}

Alasalvar, C., Pelvan, E., Özdemir, K. S., Kocadagìli, T., Mogol, B. A., Pasli, A. A., ... Gökmen, V. (2013). Compositional, nutritional, and functional characteristics of instant teas produced from low- and high- quality black teas. Journal of Agricultural and Food Chemistry, 61(31), 7529-7536. https://doi.org/10.1021/jf4015137

Deroy, O., Michel, C., Piqueras-Fiszman, B., \& Spence, C. (2014). The plating manifesto (I): from decoration to creation. Flavour, 3(1). https://doi.org/10.1186/2044-7248-3-6

Drava, G., Iobbi, V., Govaerts, R., Minganti, V., Copetta, A., Ruffoni, B., \& Bisio, A. (2020). Trace elements in edible flowers from Italy: Further insights into health benefits and risks to consumers. Molecules, 25(12). https://doi.org/10.3390/molecules2512 $\underline{2891}$

Fernandes, L., Casal, S., Pereira, J. A., Saraiva, J. A., \& Ramalhosa, E. (2017, July 1). Edible flowers: A review of the nutritional, antioxidant, antimicrobial properties and effects on human health. Journal of Food Composition and Analysis. Academic Press Inc. https://doi.org/10.1016/j.jfca.2017.03. $\underline{017}$

Guggenmos, K. dan McVety, P. J. (2010). Culinary essentials. California: McGrawHill Companies inc.

Guiné, R. P. F., Florença, S. G., Moya, K. V., \& Anjos, O. (2020). Edible flowers, old tradition or new gastronomic trend: A first look at consumption in portugal versus costa rica. Foods, 9(8). https://doi.org/10.3390/foods9080977

Hartaji, Damar A. (2012). Motivasi Berprestasi Pada Mahasiswa yang Berkuliah Dengan Jurusan Pilihan Orangtua. Fakultas Psikologi Universitas Gunadarma. (tidak diterbitkan)

Hasibuan, Malayu. (2012). Manajemen Sumber Daya Manusia. Jakarta: PT Bumi Aksara.

Husti, A., Cantor, M., Buta, E., \& Hort, D. (2013). Current Trends of Using Ornamental Plants in Culinary Arts. ProEnvironment/ProMediu, 6(13). ISSN: 2066-1363 
Karina, S. M., \& Amrihati, E. T. (2017). Pengembangan Kuliner. Jakarta: Pusdiknakes

Lesmana, S. Novian. (2020). Jurnal Artikel Teori Kesadaran. Citizenship Teaching and Learning 1(1),1-45.

Michel, C., Velasco, C., Gatti, E., \& Spence, C. (2014). A taste of Kandinsky: assessing the influence of the artistic visual presentation of food on the dining experience. Flavour, 3(1). https://doi.org/10.1186/20447248-3-7

Mubarak, W. I. (2011). Promosi Kesehatan untuk Kebidanan. Jakarta: Salemba Medika.

Notoatmodjo, Soekidjo. (2014). Metodologi Penelitian Kesehatan. Jakarta: Rineka Cipta

Nunung, \& Yauchti, D. (2011). Garnish cantik dan simpel dari sayur dan buah. Jakarta: Demedia Pustaka.

Prabawati, Sulusi. (2018). Bunga-Bunga Dalam Makanan Dan Minuman Fungsional. Bogor: Pusat Penelitian dan Pengembangan Hortikultura

Priyono, O. S. (1996). Pemberdayaan: Konsep, Kebijakan dan Implementasi. Jakarta: CSIS

Putra, A. N., Anantadjaya, S. P., \& Nawangwulan, I. M. (2020). Customer Satisfaction as A Result of Combination of Food Display \& Quality. Journal of Management and Business, 19(2). https://doi.org/10.24123/jmb.v19i2.43 $\underline{9}$

Rivas-García, L., Navarro-Hortal, M. D., Romero-Márquez, J. M., ForbesHernández, T. Y., Varela-López, A., Llopis, J., ... Quiles, J. L. (2021). Edible flowers as a health promoter: An evidence-based review. Trends in Food Science and Technology. Elsevier Ltd. https://doi.org/10.1016/j.tifs.2020.12.0 $\underline{07}$

Sudijono, Anas. (2011). Pengantar Evaluasi Pendidikan. Jakarta: Pt. Grapindo Persada.
Sugiyono. (2010). Metode Penelitian Pendidikan Pendekatan Kuantitatif, kualitatif, dan $R \& D$. Bandung: Alfabeta.

Widiasworo, Erwin. (2017). Smart Study. Jakarta: PT Elex Media Komputindo.

Yusuf, S., (2012). Psikologi Perkembangan Anak dan Remaja. Bandung: Remaja Rosdakarya. 